\section{Ultraviolet-B Radiation Damage on Kentucky Bluegrass. III. Cultivar Effects}

\author{
Erik H. Ervin, ${ }^{1}$ Xunzhong Zhang, ${ }^{2}$ and John H. Fike ${ }^{1}$ \\ Department of Crop and Soil Environmental Sciences, Virginia Polytechnic \\ Institute and State University, Blacksburg, VA 24061-0404
}

Additional index words. chlorophyll concentration, chlorophyll fluorescence, carotenoids, photochemical efficiency, Poa pratensis

\begin{abstract}
Plants possess various constitutive and inducible defense mechanisms such as pigment and antioxidant systems for protection against stresses such as ultraviolet-B (UVB; 290 to $320 \mathrm{~nm}$ ) radiation. Our previous research has indicated that higher chlorophyll, carotenoid, and anthocyanin concentrations were associated with greater tolerance of UV-B stress by 'Georgetown' kentucky bluegrass (Poa pratensis L.). The objectives of this study were to determine if kentucky bluegrass cultivars with darker leaf color possessed greater pigment and antioxidant defense systems and if such increases were associated with greater resistance to UV-B. Eight cultivars exhibiting a range of green color intensity ('Apollo', 'Brilliant', 'Julius', Limerick', 'Midnight', 'Moonlight', 'Nuglade', and 'Total Eclipse') were selected and subjected to continuous, artificial UV-B radiation $\left(70 \mu \mathrm{mol} \cdot \mathrm{m}^{-2} \cdot \mathrm{s}^{-1}\right)$. UV-B irradiation reduced turf quality $(55 \%$ to $62 \%)$ and photochemical efficiency $(37 \%$ to $70 \%)$ when measured 5 days after initiation of UV-B exposure. Significant differences in turf color, photochemical efficiency, chlorophyll a, chlorophyll b, chlorophyll $a+b$, and carotenoids were found among the cultivars. 'Moonlight' had greatest photochemical efficiency, chlorophyll, carotenoids, and turf quality. Positive correlations of pigment concentration with photochemical efficiency and turf color were observed under UV-B radiation stress, with correlation coefficients ranging from 0.49 to 0.62 . The results of this study suggests that selecting cultivars with higher concentrations of chlorophyll and carotenoids and photochemical efficiency may be an effective way for turfgrass managers and sod producers to improve sod establishment and quality in environments with higher UV-B radiation.
\end{abstract}

Kentucky bluegrass is an important turfgrass species used for sod production, lawns and athletic fields in North America. A major concern of sod producers is quality decline of sod during transport and transplantation. Supraoptimal temperature stress during sod transport can kill or severely impact the physiological integrity of turfgrass tissues (King et al., 1982; Heckman et al., 2001; Zhang et al., 2003). Exposure to high levels of UV-B (280 to $320 \mathrm{~nm}$ ) radiation at harvest and replanting, causes photooxidative stress and, in conjunction with high temperatures, further decreases the potential for posttransplant sod survival.

As stratospheric ozone depletion continues, UV-B radiation at the earth's surface increases (Bornman et al., 1997; Mackerness, 2000). A high level of UV-B irradiation has been shown to affect the regulatory mechanisms of plants, causing reductions in photosynthesis and other metabolic processes (Costa et al., 2002; Teramura and Ziska, 1996). Ultraviolet$B$ irradiation has been shown to decrease the

Received for publication14 Apr. 2003. Accepted for publication 31 Dec. 2003. This research was conducted as part of USDA-CSREES project no. VA-135660. Mention of a trademark, proprietary product, or vendor does not constitute a guarantee or warranty of the product by Virginia Tech or the U.S Dept. of Agriculture and does not imply its approval to the exclusion of other products or vendors that also may be suitable.

${ }^{1}$ Assistant professor.

${ }^{2}$ Research scientist. activity of the Photosystem II (PSII) complex with a corresponding decrease in electron transport and ATP synthesis (Noorudeen and Kulandaivelu, 1982), ultimately resulting in oxidative stress (Rao et al., 1996). High UVB may also affect photosynthesis indirectly by photobleaching and photodegradation of pigments (Strid and Porra, 1992; Takeuchi et al., 1995). As a result, turfgrass quality and photochemical activity are significantly reduced (Schmidt and Zhang, 2001).

Plants possess variable means of tolerating or avoiding UV-B stress (Caldwell et al., 1983). Various phenolic compounds, particularly flavonoids in the epidermis, will absorb UV-B and transmit nondamaging longer wavelengths (Kondo and Kawashima, 2000; PerezRodriguez et al., 1998). Antioxidants such as carotenoids have been shown to protect plants from UV-B damage (Bornman et al., 1997; Rao et al., 1996; Teramura and Ziska, 1996). Carotenoids play important protective roles and functions in light-harvesting processes, quenching of triplet state chlorophyll, and scavenging singlet oxygen and free radicals. Protection of the photosynthetic apparatus by carotenoids is essential to the survival of most plants (Pallett and Young, 1993). Under high light stress, carotenoids are destroyed at a faster rate than chlorophyll (Pallett and Young, 1993). Chlorophyll destruction may be reduced when triplet state chlorophyll is quenched efficiently by carotenoids.

Studies of UV-B irradiation effects on plants have shown a wide range of responses. Some species are particularly sensitive and show signs of damage at moderate increases in UV-B, while other species show no response (Tevini and Teramura, 1989). These differences are also found between varieties of the same species (Teramura et al., 1990). Differences in stress tolerance between closely related plant species or cultivars may be related to differences in antioxidant levels (Bowler, 1992), including carotenoids. However, no information is available concerning the variations in UV-B resistance of different cultivars of kentucky bluegrass and its relation to leaf pigment concentration. Investigations concerning the physiological basis of potential cultivar differences in UV-B stress resistance would provide valuable selection information for turfgrass breeders and sod producers. The objective of this research was to examine the relationship between phenotypic differences in color and susceptibility to UVB stress of kentucky bluegrass cultivars by measuring select pigment concentrations and leaf tissue damage.

\section{Materials and Methods}

Experiment 1. Eight kentucky bluegrass cultivars from the 2000 National Turfgrass Evaluation Program (NTEP) trial, grown on a Groseclose silt loam soil (a clayey, Kaolinitic, mesic Typic Hapludult, pH 6.0, OM 2.2\%) at the Virginia Tech Turfgrass Research Center, Blacksburg, Va., were used for this study. The trial was established in October 2000. Nitrogen applications from trial establishment up to the time of sample harvest for this experiment were as follows: $49 \mathrm{~kg} \cdot \mathrm{ha}^{-1}$ in Nov. 2000 and May $2001 ; 37 \mathrm{~kg} \cdot \mathrm{ha}^{-1}$ in July $2001 ; 98 \mathrm{~kg} \cdot \mathrm{ha}^{-1}$ in Oct. 2001; and $85 \mathrm{~kg} \cdot \mathrm{ha}^{-1}$ in Nov. 2001. The nitrogen source for all applications was a $31 \mathrm{~N}-0 \mathrm{P}-0 \mathrm{~K}$ with $28 \%$ IBDU and $3 \%$ urea. The field plots were mowed bi-weekly at $3.8 \mathrm{~cm}$ and irrigation was applied to prevent moisture stress.

Four plugs ( $10 \mathrm{~cm}$ diameter $\times 6 \mathrm{~cm}$ deep $)$ of each cultivar were taken from NTEP field plots on 18 Dec. 2001, put in PVCrings, and placed in $3 \mathrm{~L}$ containers filled with a mixture of 1 silt loam : 1 sand (by volume) and placed under a mist system in the greenhouse. Nitrogen was applied at $45 \mathrm{~kg} \cdot \mathrm{ha}^{-1}$ with a $20 \mathrm{~N}-8.6 \mathrm{P}-16.6 \mathrm{~K}$ soluble fertilizer $2 \mathrm{~d}$ after the plugs were transplanted. The cultivar transplants were grown for three weeks before initiation of UV-B treatments.

For the UV-B stress treatment, the cultivars were placed under artificial UV-B (70 $\mu \mathrm{mol} \cdot \mathrm{m}^{-2} \cdot \mathrm{s}^{-1}$ ) provided by three $40 \mathrm{~W} \mathrm{UV}-\mathrm{B}$ fluorescent lamps (Phillips UVB-313, Q-Panel Lab Products, Cleveland, Ohio). The containers were spaced evenly $(2.5 \mathrm{~cm})$, kept $0.5 \mathrm{~m}$ below the UV-B source, and grown under continuous UV-B irradiation in a greenhouse maintained at $20 \pm 2{ }^{\circ} \mathrm{C}$. Daylength averaged $11 \mathrm{~h}$. Plugs were subjected to UV-B from 9 to 18 Jan. 2002 and irrigated three times a week to prevent moisture stress. Total UV flux ( 250 to $400 \mathrm{~nm}$ ) from the fluorescent lamps was measured with a UV meter (Apogee Instruments, Inc. Logan, Utah). The meter was placed vertically with the sensor $0.5 \mathrm{~m}$ below the UV-B source. On Jan. 19, the plugs were removed from UV-B treatment and 
placed under a mist system for recovery from Jan. 19 to Feb 3.

Cultivar photosynthetic system function was measured indirectly by chlorophyll fluorescence using a dual wavelength fluorometer (OS-50, Opti-Sciences, Inc., Tyngsboro, Mass.). Photochemical efficiency (Fv690nm/Fm690nm; that is, a ratio of variable fluorescence to maximum fluorescence at $690 \mathrm{~nm}$ ) was determined from chlorophyll fluorescence signals (Zhang and Schmidt, 2000). Visual turf color during stress and recovery periods was scored based on a scale of 1 to 9 , with 9 indicating the darkest green color.

The experiment was repeated from 18 Mar. through 12 Apr. 2002. In this experiment, the cultivars were subjected to UV-B stress treatment from 18 to $22 \mathrm{Mar}$. On $23 \mathrm{Mar}$., the cultivars were removed from UV-B irradiation and placed on a mist bench for recovery from 23 Mar. through 12 Apr. Visual quality and photochemical efficiency were determined at days 1, 5, and 25 after UV-B initiation according to the procedures described previously. At the beginning of UV-B treatment, leaf samples were collected for chlorophyll and carotenoid determination.

Chlorophyll a, b, chlorophyll $\mathrm{a}+\mathrm{b}$, and carotenoids were analyzed according to the procedures of Lichtenthaler (1987). Briefly, leaf samples ( $50 \mathrm{mg}$ fresh weight) were ground in $10 \mathrm{~mL}$ of $100 \%$ acetone. The homogenate was centrifuged at $2700 g_{n}$ for $10 \mathrm{~min}$. The supernatant absorbance at 661.6, 644.8, and 470 $\mathrm{nm}$ were measured using a spectrophotometer (ThermoSpectronic, BioMate 3, Rochester, N.Y.). Chlorophyll and carotenoid concentrations were calculated by the equations of Lichtenthaler (1987) as follows:

Chl a $=(11.24 \times$ absorbance @ 661.6 nm) - (2.04 x absorbance @644.8 nm)

Chl b = (20.13 $\times$ absorbance@644.8 nm) -(4.19x absorbance @661.6 nm)

Chl $\mathrm{a}+\mathrm{b}=(7.05 \times$ absorbance @ 661.6 nm $)+$ (18.09 × absorbance @ 644.8 nm)

Carotenoids $($ xanthophylls and $\beta$-carotene $)=$ $(1000 \times$ absorbance @ $470 \mathrm{~nm})-(1.90 \times \mathrm{Chl}$ $\mathrm{a}-63.14 \times \mathrm{Chl} \mathrm{b}) / 214$.

A randomized complete block design was used with four replications. The data were analyzed using ANOVA and mean separations were performed using a Fisher's protected LSD test at $\alpha=0.05)$. Spearman correlation coefficients $(r)$ were calculated based on the individual measurements (SAS, 1988).

\section{Results}

The eight cultivars were chosen to represent a range of phenotypic color differences and possible pigment concentration differences. Based on five color ratings taken on the 2000 National Turfgrass Evaluation Program (NTEP) trial at Blacksburg, Va. over the 2001 and 2002 seasons, 'Moonlight' was classified as the darkest selection with 'Midnight', 'Nuglade', and 'Total Eclipse' being the medium-dark selections and 'Apollo', 'Brilliant', 'Julius', and 'Limerick' being the lightest green selections (Table 1). Chlorophyll and carotenoid concentrations of the leaf tissue before initiation of UV-B stress did not separate cultivars into these color classes as distinctly. However, three of the darker selections-Moonlight, Midnight, and Nuglade-contained more chlorophyll a, $\mathrm{b}, \mathrm{a}+\mathrm{b}$, and carotenoids when compared to the light green cultivar-Limerick. In addition, Brilliant contained greater chlorophyll a, a + b, and carotenoids than Limerick.

Significant positive correlations were found between initial chlorophyll concentrations and turf visual color or photochemical efficiency (Table2). However, correlations between initial carotenoids and color, and, carotenoids and photochemical efficiency were statistically significant only when color and photochemical efficiency were measured $5 \mathrm{~d}$ after UV-B initiation.

This experiment was conducted twice on the same greenhouse bench. Experimental period, when considered a factor in the analysis of variance, did not consistently have a main or interactive effect with cultivar on quality or photochemical efficiency (Table 3). Therefore, quality and photochemical efficiency data are presented as averages over both experimental periods (Table 4). The eight cultivars, easily separated by visual color in the field plots, were not as easily separated by color following greenhouse transplantation and re-growth before UV-B treatment initiation (d 1, Table 4). However, $5 \mathrm{~d}$ of continuous UV-B irradiation caused some major color separations. On average, color scores were reduced by $55 \%$ to $62 \%$ when measured $5 \mathrm{~d}$ after UV-B initiation. At $5 \mathrm{~d}$ exposure to continuous UV-B, Moonlight had maintained the most color, while Limerick color scores indicated almost complete photobleaching. Following $15 \mathrm{~d}$ of removal from UV-B (d 25), color recovered rapidly; on average, color scores improved by $69 \%$ to $105 \%$ (Table 4). At the end of the experiments, Moonlight exhibited darker color relative to the light-green classified cultivars-Brilliant, Julius and Limerick.

Greater chlorophyll and carotenoid concen- trations for the darker cultivars were also associated with higher photochemical efficiency at day 1, just before UV-B initiation (Table 4). Five days of continuous UV-B exposure resulted in photochemical efficiency reductions of $54 \%$ to $73 \%$ across the various cultivars. At day 5, Moonlight had a higher photochemical efficiency relative to the lighter-green cultivars-Total Eclipse, Brilliant, Julius, and Limerick. Fifteen days after removal of UV-B (day 25), recovery of photochemical efficiency was evident for all cultivars, although recovery of the lighter green cultivars did not reach the levels of the darker cultivars.

\section{Discussion}

The results of this study indicate that continuous UV-B irradiation $\left(70 \mu \mathrm{mol} \cdot \mathrm{m}^{-2} \cdot \mathrm{s}^{-1}\right)$ caused significant visual and photosynthetic damage to kentucky bluegrass in a short time $(5 \mathrm{~d})$. This is consistent with the results of a number of researchers (Noorudeen and Kulandaivelu, 1982; Strid and Porra, 1992; Schmidt andZhang, 2001; Ervin et al., 2004a; 2004b). Barker et al. (1997) reported that exposure of pea leaves to UV-B caused significant reductions of photochemical efficiency and photosynthetic electron transport from 12 to $80 \mathrm{~h}$ after initiation of UV-B exposure. Schmidt and Zhang (2001) indicated that three to five days of exposure to UV radiation significantly reduced photochemical efficiency and visual quality of kentucky bluegrass. Teramura andZiska(1996) concluded that increased UV-B irradiation decreases activity of the PSII complex resulting in reduced electron transport, photosynthetic capacity, and chlorophyll concentration. The results of this study indicate that kentucky bluegrass is sensitive to UV-B irradiative damage of its photosynthetic apparatus, resulting in rapid and extensive leaf injury.

Our results also indicate that differences in visual color and photochemical efficiency existed among the eight cultivars before,

Table 1. Color ratings, chlorophyll and carotenoid concentration of eight cultivars of kentucky bluegrass before being subjected to UV-B irradiation stress; Expt. 2.

\begin{tabular}{|c|c|c|c|c|c|c|}
\hline \multirow[b]{2}{*}{ Cultivar } & \multirow{2}{*}{$\begin{array}{l}\text { Color } \\
\text { category }\end{array}$} & \multirow{2}{*}{$\begin{array}{c}\text { NTEP color rating }{ }^{2} \\
1-9 \text { scale, } 9=\text { darkest }\end{array}$} & \multicolumn{3}{|c|}{ Chlorophyll $\left(\mu \mathrm{g} \cdot \mathrm{mL}^{-1}\right)$} & \multirow{2}{*}{$\begin{array}{c}\text { Carotenoids } \\
\left(\mu \mathrm{g} \cdot \mathrm{mL}^{-1}\right)\end{array}$} \\
\hline & & & $\overline{\mathrm{Chl} \mathrm{a}}$ & Chl b & $\overline{\mathrm{Chl} \mathrm{a}+\mathrm{b}}$ & \\
\hline Moonlight & Dark & $7.6 \mathrm{a}$ & $12.4 \mathrm{a}$ & $4.3 \mathrm{a}$ & $16.7 \mathrm{a}$ & $3.6 \mathrm{a}$ \\
\hline Midnight & Med-dark & $6.4 \mathrm{~b}$ & $12.4 \mathrm{a}$ & $4.3 \mathrm{a}$ & $16.7 \mathrm{a}$ & $3.6 \mathrm{a}$ \\
\hline NuGlade & Med-dark & $6.2 \mathrm{~b}$ & $12.6 \mathrm{a}$ & $4.0 \mathrm{a}$ & $16.6 \mathrm{a}$ & $3.6 \mathrm{a}$ \\
\hline Total Eclipse & Med-dark & $6.2 \mathrm{~b}$ & $10.9 \mathrm{ab}$ & $3.5 \mathrm{ab}$ & $13.4 \mathrm{ab}$ & $3.5 \mathrm{ab}$ \\
\hline Apollo & Light & $5.2 \mathrm{c}$ & $10.8 \mathrm{ab}$ & $3.3 \mathrm{ab}$ & $14.1 \mathrm{ab}$ & $3.5 \mathrm{ab}$ \\
\hline Brilliant & Light & $5.1 \mathrm{c}$ & $11.8 \mathrm{a}$ & $3.7 \mathrm{ab}$ & $15.5 \mathrm{a}$ & $3.8 \mathrm{a}$ \\
\hline Julius & Light & $5.0 \mathrm{c}$ & $10.3 \mathrm{ab}$ & $3.3 \mathrm{ab}$ & $13.6 \mathrm{ab}$ & $3.4 \mathrm{ab}$ \\
\hline Limerick & Light & $4.9 \mathrm{c}$ & $8.9 \mathrm{~b}$ & $2.8 \mathrm{~b}$ & $11.7 \mathrm{~b}$ & $2.7 \mathrm{~b}$ \\
\hline
\end{tabular}

${ }^{\mathrm{z}}$ Average of five color ratings taken over the 2001 and 2002 seasons on the 2000 kentucky bluegrass National Turfgrass Evaluation Program (NTEP) trial at Blacksburg, Va.

Table 2. Spearman correlation coefficients of pigment contents with visual color and photochemical efficiency in kentucky bluegrass; Expt. 2.

\begin{tabular}{|c|c|c|c|c|c|c|}
\hline \multirow[b]{2}{*}{ Pigment } & \multicolumn{3}{|c|}{ Visual color } & \multicolumn{3}{|c|}{ Photochemical efficiency (Fv/Fm) } \\
\hline & $1 \mathrm{~d}^{\mathrm{z}}$ & $5 d$ & $25 \mathrm{~d}$ & $1 \mathrm{~d}$ & $5 d$ & $25 \mathrm{~d}$ \\
\hline Chl a & $0.50^{* *}$ & $0.56^{* *}$ & $0.51^{* *}$ & $0.60^{* *}$ & $0.59^{* *}$ & $0.56^{* *}$ \\
\hline Chl b & $0.48^{* *}$ & $0.53^{\text {** }}$ & $0.47^{* *}$ & $0.57^{* *}$ & $0.51^{* *}$ & $0.57^{* *}$ \\
\hline $\mathrm{Chl} a+b$ & $0.40^{*}$ & $0.49^{* *}$ & $0.42^{*}$ & $0.50^{* *}$ & $0.52^{* *}$ & $0.50^{* *}$ \\
\hline Carotenoids & $0.28^{\mathrm{NS}}$ & $0.62^{* *}$ & $0.24^{\mathrm{NS}}$ & $0.33^{\mathrm{NS}}$ & $0.51^{* *}$ & $0.28^{\mathrm{NS}}$ \\
\hline
\end{tabular}

${ }^{2}$ Days after initiation of UV-B treatments.

Ns, ****Nonsignificant or significant at $5 \%$ or $1 \%$ probability level, respectively. 
Table 3. Probability of significant $\mathrm{F}$ test values for kentucky bluegrass color and photochemical efficiency responses to days of UV-B irradiance analyzed over two experimental periods

\begin{tabular}{lcccr}
\hline & & \multicolumn{3}{c}{ Day } \\
\cline { 3 - 5 } Source & df & 1 & 5 & 25 \\
\hline & & & Color & 0.01 \\
Cultivar & 7 & 0.01 & 0.01 & 0.01 \\
Experiment & 1 & 0.13 & 0.74 & 0.75 \\
Cultivar $\times$ Expt. & 7 & & Photochemical efficiency & 0.01 \\
Cultivar & 7 & 0.02 & 0.06 & 0.17 \\
Experiment & 1 & 0.01 & 0.01 & 0.52 \\
Cultivar $\times$ Expt. & 7 & 0.59 & & 0.95 \\
\hline
\end{tabular}

Table 4. Visual color and photochemical efficiency of eight cultivars of kentucky bluegrass subjected to UV-B radiation stress; means over both experimental runs. Days after initiation of UV-B treatment; continous UV-B exposure lasted $10 \mathrm{~d}$, with $15 \mathrm{~d}$ of recovery.

\begin{tabular}{|c|c|c|c|c|c|c|}
\hline \multirow[b]{2}{*}{ Cultivar } & \multicolumn{3}{|c|}{ Visual color (1-9 with $9=$ darkest $)$} & \multicolumn{3}{|c|}{ Photochemical efficiency (Fv/Fm) } \\
\hline & $1 \mathrm{~d}^{\mathrm{z}}$ & $5 \mathrm{~d}$ & $25 \mathrm{~d}$ & $1 \mathrm{~d}$ & $5 \mathrm{~d}$ & $25 \mathrm{~d}$ \\
\hline$\overline{\text { Moonlight }}$ & $9.0 \mathrm{a}$ & $4.9 \mathrm{a}$ & $7.6 \mathrm{a}$ & $0.61 \mathrm{a}$ & $0.28 \mathrm{a}$ & $0.50 \mathrm{a}$ \\
\hline Total Eclipse & $8.7 \mathrm{ab}$ & $2.3 \mathrm{de}$ & $6.6 \mathrm{ab}$ & $0.55 \mathrm{ab}$ & $0.15 \mathrm{~b}$ & $0.49 \mathrm{ab}$ \\
\hline Midnight & $8.6 \mathrm{~b}$ & $3.0 \mathrm{~cd}$ & $7.1 \mathrm{ab}$ & $0.52 \mathrm{bc}$ & $0.21 \mathrm{ab}$ & $0.49 \mathrm{ab}$ \\
\hline Julius & $8.5 \mathrm{~b}$ & $2.9 \mathrm{~cd}$ & $6.3 \mathrm{~b}$ & $0.52 \mathrm{bc}$ & $0.18 \mathrm{~b}$ & $0.36 \mathrm{c}$ \\
\hline Apollo & $8.5 \mathrm{~b}$ & $4.1 \mathrm{ab}$ & $6.8 \mathrm{ab}$ & $0.55 \mathrm{ab}$ & $0.23 \mathrm{ab}$ & $0.43 \mathrm{abc}$ \\
\hline Brilliant & $8.4 \mathrm{~b}$ & $3.4 \mathrm{bc}$ & $6.4 \mathrm{~b}$ & $0.52 \mathrm{bc}$ & $0.19 b$ & $0.39 \mathrm{bc}$ \\
\hline Nuglade & $8.3 \mathrm{~b}$ & $3.6 \mathrm{bc}$ & $6.9 \mathrm{ab}$ & $0.54 \mathrm{bc}$ & $0.23 \mathrm{ab}$ & $0.52 \mathrm{a}$ \\
\hline Limerick & $7.7 \mathrm{c}$ & $1.6 \mathrm{e}$ & $4.4 \mathrm{c}$ & $0.48 \mathrm{c}$ & $0.15 \mathrm{~b}$ & $0.35 \mathrm{c}$ \\
\hline
\end{tabular}

${ }^{2}$ Values followed by same letters within same column are not different significantly at LSD (0.05).

during, and after UV-B stress. The darkest green cultivar-Moonlight-possessed greater chlorophyll and carotenoid concentrations, a condition positively associated with greater tolerance of (and recovery from) UV-B. These results suggest that selection of darker green kentucky bluegrass cultivars may provide better performance in high UV-B (higher altitude, semi-arid) climates. Another useful application of these results involves summer transplant success of kentucky bluegrass sod. Supraoptimal heating of sod while on the pallet predisposes leaf tissues to further damage when transplanted to a high UV-B field environment. Use of darker green kentucky bluegrass cultivars in sod production may serve to dampen the damaging effects of UV-B and improve summer transplanting. Further research investigating the interaction of heat and UV-B stress on sod transplanting success of variously colored kentucky bluegrass cultivars is required to confirm these suppositions. As incident UVB levels continue to rise due to stratospheric ozone depletion, turfgrass breeders, growers, and practitioners may want to consider selecting darker green cultivars with higher pigment concentrations. As these data and those of the two companion papers indicate, utilizing cultivars with greater genetic resistance to UV-B, in combination with exogenous applications of various hormone, colorant, and antioxidant supplements before imposed or predicted periods of high environmental stress may bolster kentucky bluegrass defense systems sufficiently to provide improved performance and persistence.
Kondo, N. and M. Kawashima. 2000. Enhancement of the tolerance to oxidative stress in cucumber (Cucumis sativus L.) seedlings by UV-B irradiation: Possible involvement of phenolic compounds and antioxidant enzymes. J. Plant Res. 113:311-317.

Lichtenthaler, H.K. 1987. Chlorophylls and carotenoids: pigments of photosynthetic biomembranes. Methods Enzymol. 148:350-382.

Mackerness, S.A.H. 2000. Plant responses to ultraviolet-B (UV-B: 280-320 nm) stress: what are the key regulators? Plant Growth Regulat. 32:27-39.

Noorudeen, A.M. and G. Kulandaivelu. 1982. On the possible site of inhibition of photosynthetic electron transport by ultrabiolet-B (UV-B) radiation. Physiol. Plant 55:161-166.

Pallet, K.E. and A.J. Young. 1993. Carotenoids, p. 59-90. In R.G. Alscher and J.L. Hess (eds.). Antioxidants in higher plants. CRC Press, Inc. Boca Raton, Fla.

Perez-Rodriguez, E., I. Gomez,U. Karsten, and F.L. Figueroa. 1998. Effects of UV radiation on photosynthesis and excretion of UV-absorbing compounds of Dasycladus vermicularis (Dasycladales, chlorophyta) from southern Spain. Phycologia 37:379-387.

Rao, M.V., G. Paliyath, and D.P. Ormrod. 1996. Ultraviolet-B and ozone-induced biochemical changes in antioxidant enzymes of Arabidopsis thaliana. Plant Physiol. 110:125-136.

SAS Institute Inc. 1988. SAS/STAT use's guide. Release 6.03 ed. SAS Inst. Inc., Cary, N.C.

Schmidt, R.E. and X. Zhang. 2001. Alleviation of photochemical activity decline of turfgrasses exposed to soil moisture stress or UV radiation. Intl. Turfgrass Res. J. 9:340-346.

Strid, A. and R.J. Porra. 1992. Alterations in pigment concentration in leaves of Pisum sativum after exposure to supplementary UV-B. Plant Cell Physiol. 33:1015-1023.

Strid A., W.S. Chow, and J. Anderson. 1990. Effects of supplementary ultraviolet-B radiation on photosynthesis in Pisum sativum. Biochim Biophy Acta. 1020:260-268.

Takeuchi, Y., Fukumoto, R., Kasahara, H., Sakaki, T., and K. Mitsutoshi. 1995. Peroxidation of lipids and growth inhibition induces by UV-B irradiation. Plant Cell Environ. 14:566-570.

Teramura, A. H and L.H. Ziska.. 1996. Ultraviolet-B radiation and photosynthesis, p. 435-450. In: Neil R. Baker (ed.). Photosynthesis and the environment. Kluwer Academic Publ., Dordrecht, The Netherlands.

Teramura, A.H., J.H. Sullivan, and L.H. Ziska. 1990. Interaction of elevated ultraviolet $\mathrm{B}$ radiation and $\mathrm{CO}_{2}$ on productivity and photosynthetic characteristics in wheat, rice, and soybean. Plant Physiol. 94:470-475.

Tevini, M. and A.H. Teramura. 1989. UV-B effects on terrestrial plants. Photochem. Photobiol. 50:479-487.

Zhang, X. and R.E. Schmidt. 2000. Application of trinexapac-ethyl and propiconazole enhances superoxide dismutase and photochemical activity in creeping bentgrass. (Agrostis stoloniferous var. palustris). J. Amer. Soc. Hort. Sci. 125:47-51.

Zhang, X., E. Ervin, and R.E. Schmidt. 2003. Plant growth regulators can enhancethe recovery of kentucky bluegrass sod from heat injury. Crop Sci. 43(3):952-956. 